\title{
燃焼合成法による $\mathrm{Sm}-\mathrm{Fe}$ 系合金の作製とその磁気特性に及ぼす 衝撃圧縮の効果
}

\author{
野口正広・友重竜一・池辺雅彦・加藤昭夫 · 今村喜八郎* ·千葉 昂* \\ 熊本工業大学応用化学科, 860-0082 熊本市池田 4-22-1 \\ *熊本大学工学部知能生産システム工学科, 860-8555 熊本市黒髮 2-39-1
}

\section{Preparation of Alloy in the Sm-Fe System by Combustion Synthesis and the Effect of Shock Compaction on Their Magnetic Properties}

\author{
Masahiro NOGUCHI, Ryuichi TOMOSHIGE, Masahiko IKEBE, Akio KATO, \\ Kihachiro IMAMURA* and Akira CHIBA*
}

\begin{abstract}
Department of Applied Chemistry, Kumamoto Institute of Technology, 4-22-1, Ikeda, Kumamoto-shi 860-0082
*Department of Mechanical Engineering and Materials Science, Faculty of Engineering, Kumamoto University, 2-39-1, Kurokami, Kumamoto-shi 860-8555
\end{abstract}

\begin{abstract}
In this study, self-propagating high temperature synthesis (SHS) reaction was utilized for the production of $\mathrm{Sm}-\mathrm{Fe}$ alloys which are precursor for Sm-Fe-N system hard magnetic materials. A main goal was to shorten the processing time required for the alloy production. Furthermore, super high pressure by explosive shock compaction method was applied to the alloys obtained by SHS reaction for very short time. The effect of the high pressure on the crystal structures was also investigated. Samarium and iron powders were used as raw materials. Mixture molar ratios of theses powders were varied from $\mathrm{Sm}: \mathrm{Fe}=2: 7$ to $2: 17$ in order to find the optimum condition. The SHS reaction was initiated by a tungsten heating coil. Although variation in temperature, resulting from the synthesis reaction, was significantly abrupt at the initial stage (i.e., for 15 s), the temperature gradually decreased from the maximum temperature. Specimens showed a similar tendency for the variation in synthesis temperature, and attained a maximum at about $1200^{\circ} \mathrm{C}$, except for the specimen with a composition of $\mathrm{Sm}: \mathrm{Fe}=2: 17$. From the results of X-ray diffraction (XRD), an expected $\mathrm{Sm}_{2} \mathrm{Fe}_{17}$ phase, and small amounts of $\mathrm{SmFe}_{2}, \mathrm{SmN}$, and $\alpha-\mathrm{Fe}$ phases were detected. The magnetic properties were also studied on as-SHSed, explosively hot-compacted, and cold-compacted specimens. Pulverized SmFe alloys, obtained by SHS reaction, were used as raw materials for the cold compaction. The cold-compacted specimen had relatively good magnetic properties. It was considered that the lattice defects introduced by the shock processing, which made a crystal lattice distorted, improved the coercive force.
\end{abstract}

[Received December 17, 1998; Accepted May 17, 1999]

Key-words : SHS, Shock compaction, Hard magnetic materials, Magnetic properties, Microstructures

\section{1. 緒 言}

高い発熱反応を伴う自己伝ぱ高温合成（self-propagating high temperature synthesis : SHS) 法は，適切な条件下におい て自発的に化学反応が進行するので外部からの加熱を必要とせ ず，各種セラミックスや金属間化合物を高速かつ低コストで合 成できる新技術として注目を集めている1)。著者らの研究グ ループでは，これまでに SHS 法と，爆薬の爆発に伴い発生す る超高圧力を利用した，いわゆる衝撃圧縮法を組み合わせた複 合プロセスにより，極短時間で高機能性無機材料の作製を試 みてきた. その結果, $\mathrm{TiC}$ 単相材 ${ }^{2)}, \mathrm{TiC} / \mathrm{Al}_{2} \mathrm{O}_{3}{ }^{3)}$ 及び $\mathrm{TiB}_{2} /$ $\mathrm{TiN}^{4)}$ の複合材料, そして $\mathrm{TiC} / \mathrm{Ti}_{4} \mathrm{Al}_{2} \mathrm{C}_{2} / \mathrm{TiAl}$ 系傾斜組成機能 材料5)等の作製において，いずれの場合も高密度で機械的特 性，耐食性に優れた材料を瞬時に得られることを報告してき た。一方，1990年にCoeyと Sun'6)によって発表された $\mathrm{Sm}_{2} \mathrm{Fe}_{17} \mathrm{~N}_{x}$ 金属間化合物は, 高い磁気異方性及びキュリ一温 度などの優れた磁気特性を持つ次世代高性能永久磁石材料とし て注目され，多くの研究が現在も行われている7). しかしなが ら,この $\mathrm{Sm}_{2} \mathrm{Fe}_{17} \mathrm{~N}_{x}$ 化合物は約 $600^{\circ} \mathrm{C}$ 以上の温度に打いて, $\mathrm{SmN}+\mathrm{Fe}_{4} \mathrm{~N}+\alpha$ - $\mathrm{Fe}$ に分解するため ${ }^{8)}$, 従来の融解鋳造や焼結 法等では作製が困難である，最近の研究では，Sm-Fe-N 系化 合物を合成する第一段階として, 金属原料粉末をメカニカルグ ライディング9)する方法やHydrogenation Decomposition Desorption Recombination (HDDR) 法 ${ }^{10}$ ) 等の処理を行った
後, 窒化処理をすることで, いずれも高磁気特性を持つ化合物 が得られている.しかし，これらのプロセスには，合成時に長 時間の複雑な処理が必要であるため, 製造技術及びコストの点 から問題が残されている. そこで本研究は, Sm-Fe-N 系化合 物の前駆物質である $\mathrm{Sm}-\mathrm{Fe}$ 系合金の作製に関して, SHS 反 応を利用することで短時間・低コスト化が可能と考え, 新規製 造プロセスの開発を試みた。 また, SHS 反応によって得られ た試料について, 熱間又は冷間で爆発衝撃圧縮を行い, Sm$\mathrm{Fe}$ 系合金の磁気特性に与える衝撃圧縮の効果についても検討 した.

\section{2. 実験方法}

本実験に用いた原料粉末はサマリウム（Sm; 高純度化学研 究所製, 平均粒径: 約 $250 \mu \mathrm{m}$, 純度 : $99.9 \%$ ） と鉄 ( $\mathrm{Fe}$; 高 純度化学研究所製, 平均粒径: 約 $2 \sim 3 \mu \mathrm{m}$, 純度 : $99 \%$ 以上) の 2 種類である. 両粉末はモル比 ( $\mathrm{Sm}: \mathrm{Fe}$, 以下 $R$ と略す) で $R=2: 7,2: 11,2: 14$ そして $2: 17$ の比で秤量し, 目的とす る $\mathrm{Sm}_{2} \mathrm{Fe}_{17}$ 相が最も多量に得られる最適条件を求めた.これ らの粉末は大気中で約 $10 \mathrm{~min}$ 乾式混合した後, SHS 反応に供 した.この $(\mathrm{Sm}+\mathrm{Fe})$ 混合粉末は断熱燃焼温度, $T_{\mathrm{ad}}$, が低 く自発的な反応が起こりにくいため, Ti（住友シチックス製, 平均粒径: 約 $45 \mu \mathrm{m}$, 純度 : $99.4 \%$ 以上), $\mathrm{Al}$ （東洋アルミニ ウム製, 平均粒径: 約 $17 \mu \mathrm{m}$, 純度: $99.87 \%$ ）及び graphite 
(a)

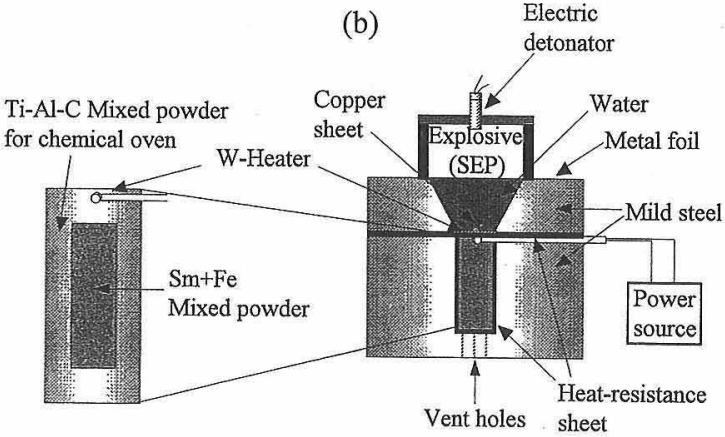

Fig. 1. Schematic illustration of assembly for hot-shock compaction.

(Aldrich Chemical 製，平均粒径：約 1 2 $\mu \mathrm{m}$ ，純度 : 99\%) の粉末からなる chemical oven を，図 1 (a)のように, SHS 反 応容器内で $(\mathrm{Sm}+\mathrm{Fe})$ 混合粉末の周团に配した。この chemi$\mathrm{cal}$ oven 用の混合粉末は，エタノール中で $1 \mathrm{~h}$ 湿式混合を行 い，十分乾燥させた後に使用した。本実験では，まずはじめ に，タングステンヒーターの熱により，上述の chemical oven が(1)式の SHS 反応を起こし，それに伴う高い合成反応熱（約 $2200 \mathrm{~K})$ が，その内側にある $(\mathrm{Sm}+\mathrm{Fe})$ 混合粉体の SHS 反 応を誘発・促進させ, $\mathrm{Sm}_{2} \mathrm{Fe}_{17}$ 相が得られるように設計した。

$$
10 \mathrm{Ti}+3 \mathrm{Al}+7 \mathrm{C} \longrightarrow 4 \mathrm{TiC}+\frac{3}{2} \mathrm{Ti}_{4} \mathrm{Al}_{2} \mathrm{C}_{2}
$$

次に，本実験で用いた熱間衝撃圧縮装置の模式図を図 1 (b)に 示す, 装置は上部から爆薬充填容器, 水槽及び SHS 反応容器 の三つで構成されている. 爆薬充填容器は塩化ビニール製で, 他の二つは軟鋼製である.まず SHS 反応容器部について説明 する. 容器の内壁（直径 $20 \mathrm{~mm} \times$ 深さ $30 \mathrm{~mm}$ ）には, 前報2) 5) と同様に, 燃焼合成時に生じる高い熱量が軟鋼製容器へ拡散し ないように, 厚さ約 $1 \mathrm{~mm}$ の断熱シート（日本バルカー工業 製，バルカーパック）を内張りした. 試料の $(\mathrm{Sm}+\mathrm{Fe})$ 混合 粉末を, 直径 $10 \mathrm{~mm}$, 高さ $15 \mathrm{~mm}$ の円柱状に成形した後, 容 器内でその周团をTi-A1-C 系混合粉末で充埧した（図 1 (a)). その後, 反応容器内の充媜粉末の上部に埋設したコイル状のタ ングステンヒーター (ニラコ製, 線径 $0.45 \mathrm{~mm}$ ) に通電するこ とで反応を開始させた。 なお，SHS反応初期温度は室温で あった。 また，反応時の燃焼温度の変化も測定した。燃焼温度 は, SHS 反応容器下部の通気孔から, Pt-PtRh 熱電対を ( Sm $+\mathrm{Fe}$ ）混合粉体中央に挿入し，熱電指示温度計を用いて， SHS 反応開始から $5 \mathrm{~s}$ 間隔で $3 \mathrm{~min}$ 測定を行った。次に熱間 衝撃圧縮実験には，硝酸エステルを主成分とする爆曘速度約 $6900 \mathrm{~m} / \mathrm{s}$ の可塑性爆薬（SEP : Slurry for Explosion, 旭化成 工業製）を用い, 直径 $50 \mathrm{~mm}$, 高さ $17 \mathrm{~mm}$ の円柱状に成形し た後, 水槽上部に固定した. 爆薬は, 後述 (3.1節) の, 最適 条件である SHS 反応開始から $60 \mathrm{~s}$ 後に，爆薬上部の電気雷管 により起爆させた，次に，冷間衝撃圧縮実験装置を図 2 に示す が，熱間衝撃圧縮装置（図 1 (b)）と異なる点は，爆薬充填容 器が軟鋼製で, 直径 $34 \mathrm{~mm}$, 薬高30 mmの円柱状に爆薬を成 形したこと，そして粉末充填容器の内径が $12 \mathrm{~mm}$ であること である。被圧縮材には，あらかじめSHS 法により合成した $\mathrm{Sm}-\mathrm{Fe}$ 系合金を，n-ヘプタン（和光純薬工業製，純度 $99 \%$ ) を入れたアルミナ乳鉢中で酸化を防ぎながら，80 mesh 以下ま で粉砕したものを用いた，十分に乾燥させた後，衝撃圧縮装置 の粉末充填容器内（図 2 の下部）へ充填した後, 室温で直ち に爆薬を起爆させて厌縮成形体を得た．本実験装置における水

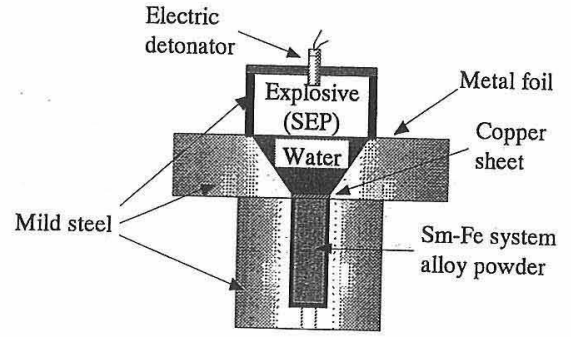

Fig. 2. Schematic illustration of assembly for cold-shock compaction.

中衝撃波の衝擊圧力は，以前行った実験結果から試料に入射 する直前で，熱間衝撃圧縮では約 $5 \mathrm{GPa}^{11)}$ ，冷間で約 $10 \sim 20$ $\mathrm{GPa}^{12)}$ と見積もられている。な抄衝撃圧縮実験は熊本大学工学 部附属衝撃エネルギー実験所にて行った.

本実験より得られた試料は, $\mathrm{X}$ 線回折（XRD；理学電機製， RINT2500 ultraX 18，線源： $\mathrm{Cu} \mathrm{K} \alpha$ )，走査型電子顕微鏡 (SEM；日本電子製，JSM-6301F）による微細組織観察，なら びにエネルギー分散型 X 線解析装置（EDS ; Oxford 製, ISIS Series 300）による組成分析，及び試料断面における元素マッ ピングを行った．磁気特性は振動試料型磁力計（VSM；玉川 製作所製，TMVSM2430MH-HGC）を用い，最大印加磁場 $1.6 \mathrm{MA} / \mathrm{m}$ で，反磁界補正なしで評価した。

\section{3. 結果及び考察}

\section{1 断熱燃焼温度変化及び最適熱間衝撃圧縮条件の決定}

図 3 に各種組成における混合粉末の燃焼温度の測定結果を示 す. 図より，本系における反応の最高到達温度は $R=2: 7 \sim 2: 14$

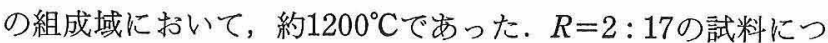

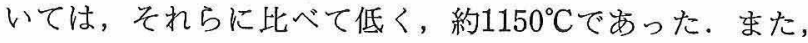
$R=2: 17$ 組成のものは, 反応初期段階の立ち上がり方が他の ものと比べて遅いことが分かる．しかしながら，Fe の配合割

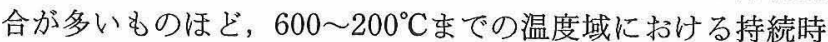
間は，長くなる傾向があった，図 4 に Sm-Fe 系の相図を示す が13), SHS 反応による本系試料の最高到達温度域はいずれも $\left(\mathrm{Sm}_{2} \mathrm{Fe}_{17}\right.$ 十液相）の範囲にあることが分かる。これを $1010^{\circ} \mathrm{C}$ まで冷却することで $\mathrm{Sm}_{2} \mathrm{Fe}_{17}$ 相が得られることが期待される. ところで, 本実験では SHS 反応直後に爆薬を用いた熱間衝撃 王縮を行うが，その際考虑しておかなければならない点は，瞬

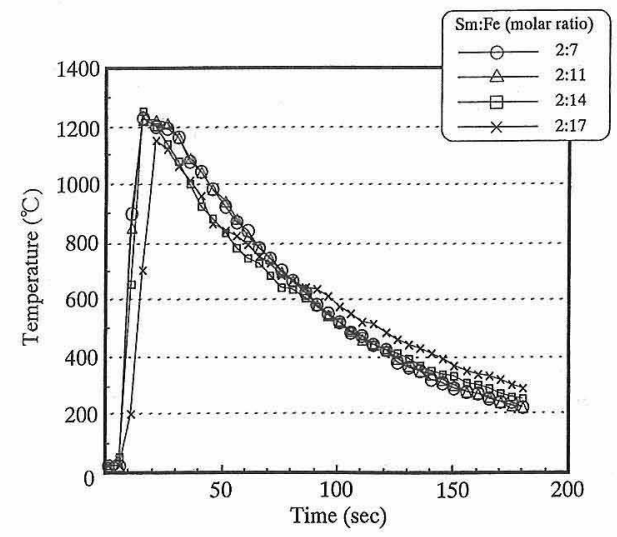

Fig. 3. Typical temperature-time histories during combustion synthesis. 


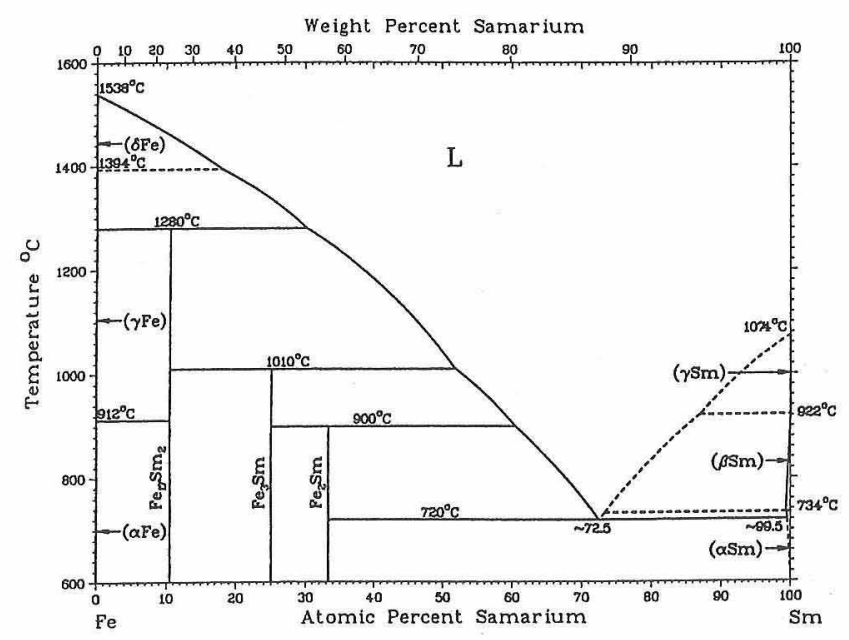

Fig. 4. Phase diagram for Sm-Fe system. ${ }^{13)}$

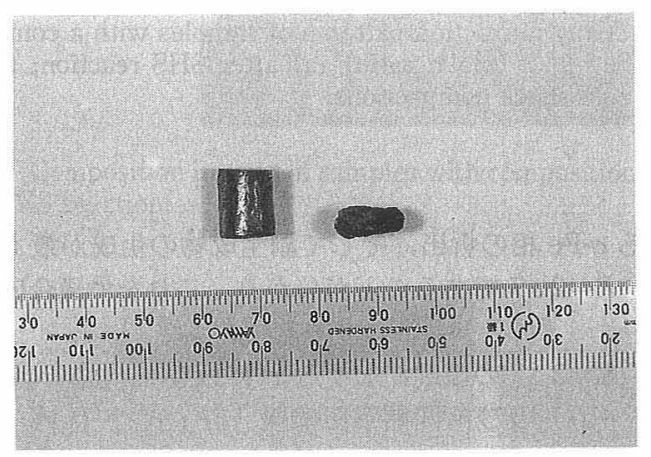

Fig. 5. Photograph of the hot-shock compacted (right) and assynthesized $\mathrm{Sm}-\mathrm{Fe}$ system alloys (left).

間的な超高圧力の負荷のために固体間の圧縮成形（ミクロ的に は局所的な粒子間摩擦による結合）が妨げられないようにする ことである。すなわち，反応中に生成した液相が固化するまで 冷却すること，及び反応時に発生する不純物ガスを試料から十 分放出させることである. それゆえ，本実験では，上記 $T_{\mathrm{ad}}$ の 測定結果から，すべての試料が固相領域にある約 $800^{\circ} \mathrm{C}$ 温度 域, すなわち SHS 反応開始か $560 \mathrm{~s}$ 後に衝撃圧力を負荷し た. 図 5 にSHS 反応で得られた試料（左側）々熱間で衝撃圧 縮した試料（右側）の外観を示す. 衝撃圧縮した試料は圧力負 荷前と比較すると，およそ $1 / 3$ 程度に圧縮されていることが 分かる.なお，冷間衝撃圧縮材についても同様な緸密体を得る ことができた。

\section{2 生成物の同定}

永久磁石材料において，大きなエネルギ一積を得ることは重 要であり，そのためには，軟磁性相である $\alpha-\mathrm{Fe}$ の析出や副生

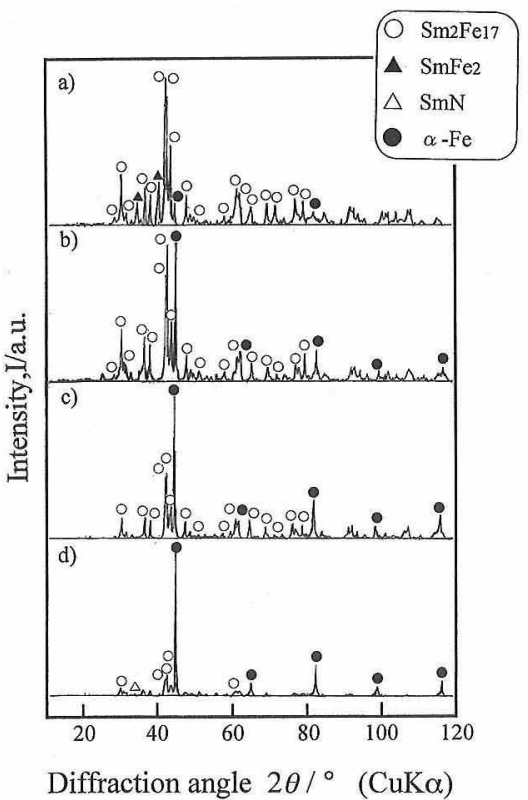

Fig. 6. X-ray diffraction patterns of samples with compositions of (a) $\mathrm{Sm}: \mathrm{Fe}$ (molar ratio) $=2: 7$, (b) $2: 11$, (c) $2: 14$ and (d) 2 : 17 produced by the SHS reaction.

成物及び酸化物相の生成を合金合成段階で抑える必要がある. 例えば $\alpha$ - Fe が数\%程度混在する場合, 王粉磁石の最大エネル ギー積値は， $\alpha$ - $\mathrm{Fe}$ が存在しないときの約半分まで減少するこ とが知られている14). 本実験においても, $R=2: 7 \sim 2: 17$ の 組成のうち, $\alpha-\mathrm{Fe}$ の析出が最も少ない組成を $\mathrm{X}$ 線回折結果か ら調べた. 図 6 にSHS 反応で得られた試料のX 線回折パター ソを示す. 上加順に図 6 (a) $R=2: 7$, (b) $2: 11$, (c) $2: 14$, (d) $2: 17$ 組成に対応しており, いずれむ酸化物は確認さ れなかった. 図6 (a)で $\mathrm{Sm}_{2} \mathrm{Fe}_{17} \mathrm{~N}_{x}$ 化合物の前駆物質である $\mathrm{Sm}_{2} \mathrm{Fe}_{17}$ 相，そして $\mathrm{SmFe}_{2}$ 相及び $\alpha-\mathrm{Fe}$ 相が, 図 6 (b) 及び (c)においては $\mathrm{Sm}_{2} \mathrm{Fe}_{17}$ 相と $\alpha-\mathrm{Fe}$ 相が検出された. 更に, 同 図(d)では $\mathrm{Sm}_{2} \mathrm{Fe}_{17}$ 相と $\alpha$ - $\mathrm{Fe}$ 相に加え, $\mathrm{SmN}$ も確認された. この $\mathrm{SmN}$ は空気中の䇪素を源として生成したと考えられる. ここで, $\mathrm{SmN}$ の生成が妥当であるが判断するために, 次式 (2)，(3) 式に基づいた $\mathrm{Sm}_{2} \mathrm{O}_{3}$ と $\mathrm{SmN}$ の熱力学的安定性から考 察した.

$$
\begin{aligned}
& \mathrm{Sm}+1 / 2 \mathrm{~N}_{2} \longrightarrow \mathrm{SmN} \\
& \mathrm{Sm}+3 / 4 \mathrm{O}_{2} \longrightarrow 1 / 2 \mathrm{Sm}_{2} \mathrm{O}_{3}
\end{aligned}
$$

$\mathrm{SmN}$ に関する熱力学的データが不明であるため, 内遷移元 素を構成しているランタノイドが化学的に非常に似た性質でめ ることを考慮し, 推定法を用いて次のような概算值を求めた。 まず希土類元素の塩化物, フッ化物, 硫化物及び窒化物の $1000 \mathrm{~K}$ における標準生成自由エネルギー， $\Delta G_{\mathrm{f}}$ の值贞),16) を酸 化物の $\Delta G_{\mathrm{f}}$ 值で規格化した值を表 1 に示した.ここで, 希土

\begin{tabular}{|c|c|c|c|c|c|c|c|c|c|c|c|c|c|c|c|}
\hline $\mathrm{R}=$ & $\mathrm{La}$ & $\mathrm{Ce}$ & $\operatorname{Pr}$ & $\mathrm{Nd}$ & $\mathrm{Pm}$ & $\mathrm{Sm}$ & $\mathrm{Eu}$ & $\mathrm{Gd}$ & $\mathrm{Tb}$ & Dy & Ho & Er & $\mathrm{Tm}$ & $\mathrm{Yb}$ & $\mathrm{Lu}$ \\
\hline$\Delta \mathrm{G}_{\mathrm{r}}\left(\mathrm{RCl}_{3}\right) / \Delta \mathrm{G}_{\mathrm{r}}\left(\mathrm{R}_{2} \mathrm{O}_{3}\right)$ & 0.550 & 0.537 & 0.536 & 0.526 & - & 0.512 & 0.509 & 0.499 & - & 0.476 & 0.477 & 0.467 & 0.464 & 0.471 & - \\
\hline$\Delta G_{i}\left(R_{F}\right) / \Delta G_{i}\left(R_{2} O_{3}\right)$ & 0.964 & 0.952 & 0.949 & 0.941 & - & - & 0.977 & 0.942 & - & 0.920 & 0.909 & 0.899 & 0.792 & - & - \\
\hline$\Delta \mathbf{G}_{\mathbf{f}}(\mathbf{R S}) / \Delta \mathbf{G}_{\mathbf{f}}\left(\mathbf{R}_{2} \mathrm{O}_{3}\right)$ & 0.280 & 0.278 & 0.269 & 0.269 & - & - & 0.272 & - & - & - & - & - & - & - & - \\
\hline$\Delta \mathbf{G}_{\mathbf{r}}(\mathbf{R N}) / \Delta \mathbf{G}_{\mathrm{f}}\left(\mathbf{R}_{2} \mathrm{O}_{3}\right)$ & 0.130 & 0.139 & - & - & - & $(0.13)$ & - & - & - & - & - & - & - & - & - \\
\hline
\end{tabular}

Table 1. $\Delta G_{\mathrm{f}}$ Values of Various Rare-Earth Compounds Standardized by the Value of Oxides 
Table 2. Comparison in Standard Formation Free Energy for $\mathrm{Sm}_{2} \mathrm{O}_{3}$ (Cubic) and $\mathrm{SmN}$

\begin{tabular}{rcc}
\hline \multirow{2}{*}{$\mathrm{T}(\mathrm{K})$} & \multicolumn{2}{c}{$\Delta \mathrm{G}_{\mathrm{f}}(\mathrm{kJ} / \mathrm{mol})$} \\
& $1 / 2 \mathrm{Sm} 2 \mathrm{O} 3$ (cubic) & $\mathrm{SmN}$ \\
\hline \hline 300 & -868 & -226 \\
400 & -853 & -222 \\
500 & -839 & -218 \\
600 & -824 & -214 \\
700 & -809 & -210 \\
800 & -795 & -207 \\
900 & -780 & -203 \\
1000 & -766 & -199 \\
1100 & -751 & -195 \\
1200 & -736 & -191 \\
1250 & -729 & -190 \\
\hline
\end{tabular}

類元素の原子番号が大きくなるにつれて, 規格化された值に連 続性があれば，希土類酸化物と未知化合物の $\Delta G_{\mathrm{f}}$ の比をこの 值から類推することができる．表 1 より，規格化された值は 希土類の塩化物, フッ化物及び硫化物と各希土類酸化物間にお いて，ほぼ連続した值を持つので窒化物についても同様の傾向 があると考えられる. 以上の方法で得られた $\mathrm{Sm}_{2} \mathrm{O}_{3}$ に対する $\mathrm{SmN}$ の $\Delta G_{\mathrm{f}}$ 比は, 約 0.13 と推定される（表 1).この值から 各温度における $\mathrm{SmN}$ の $\Delta G_{\mathrm{f}}$ は表 2 に示したような值を取る ものと思われる.これより窒化物の生成は可能と考えられる が, その生成過程は, 鉄と反応しなかったサマリウムが, 粉末 表面で SHS 反応時の高温下で窒素と反応した結果と考えた.

また, それよりも低い $\Delta G_{f}$ 值を持つ酸化物が前出の $\mathrm{X}$ 線回折 （図 6）で見られなかったのは, 大気中の窒素と酸素の存在割 合（窒素 : 酸素 $=4: 1$ ) に起因した酸化物生成量の少なさにあ ると推測した. また, $\mathrm{Sm}-\mathrm{Fe}-\mathrm{N}$ 系磁性体の生成との関連につ いて,この結果からは示唆されなかった.

次に, X 線回折結果（図 6) より, 出発原料組成での Fe の 割合が減るにつれて, 生成する $\mathrm{Sm}_{2} \mathrm{Fe}_{17}$ 相は相対的に増加し, 末反応の $\alpha-\mathrm{Fe}$ 相が減少していることが分かる. ところで出発 原料組成において, $R=2: 14$ から $2: 7$ へと $\mathrm{Sm}$ の量が増加す るにつれて，反応が活性になり，大きな空隙が見られるように なった．これは，Smの蒸気圧が高く, SHS 反応初期段階で の急加熱，もしくは最高温度到達時における $\mathrm{Sm}$ の気化が原因 と考えられる7). 実際, 更に Sm-rich 組成にした $R=2: 6$ では, $\mathrm{SHS}$ 反応中に $\mathrm{Sm}$ の気化がより激しくなり, 試料はほとんど 回収できなかった．なた，本試料は $\mathrm{Fe}$ と Sm の自己拡散係数 の差と, SHSによる反応時間が極端に短いことに起因した Fe-rich $の \mathrm{SmFe}_{2}$ 相の生成, 及び末反応 $\alpha$ - Fe 相の残留など, 反応経路に急加熱・急冷過程を有する SHS 反応の特徵1)を強 く反映していると言える，このように，良好な磁気特性を得る ために必要な試料の単相化は, 今回の 1 ステップ製法では達 成することは困難であったが，熱処理等と組み合わせることに より今後改良できると思われる. 以上の結果から, 本実験条件

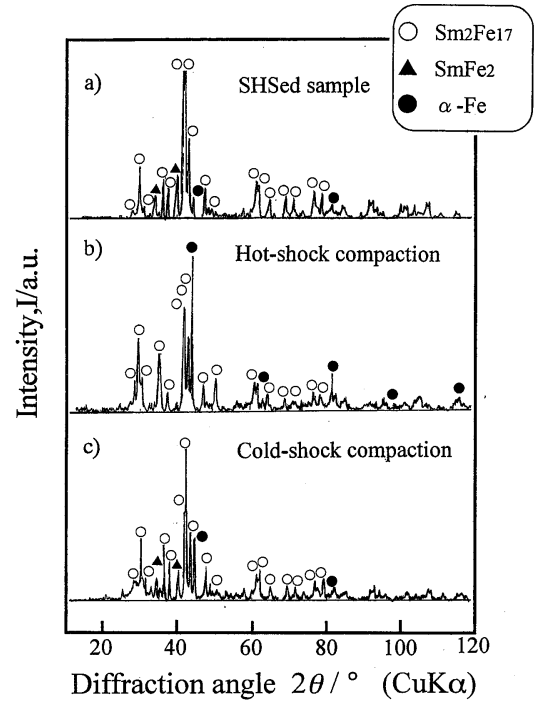

Fig. 7. X-ray diffraction patterns of samples with a composition of $\mathrm{Sm}: \mathrm{Fe}=2: 7$ (molar ratio) (a) after SHS reaction, (b) hot-, and (c) cold-shock compactions.

における $\alpha-\mathrm{Fe}$ 相の析出, そして副生成物の生成が最も少ない 組成は， $R=2: 7$ であることが分かり，これを最適合成条件と して用いた.

次に, $R=2: 7$ の組成に抢ける SHS 反応後（図 7 (a)）と熱 間（図 7 (b)）及び冷間衝撃圧縮後（図 7 (c)）に得られた試 料の X 線回折パターンを示す. SHS 反応後と冷間衝撃圧縮後 の試料に打いては, $\mathrm{Sm}_{2} \mathrm{Fe}_{17}$ 相と $\alpha-\mathrm{Fe}$ 相を示す回折線の強度 比にほとんど差は見られないが，熱間衝撃圧縮後の試料におい て， $\alpha$ - Fe 相を示す回折線の強度が増加していることが分かる. これは, 図 7 (a)及び(c)でみられた $\mathrm{SmFe}_{2}$ 相が熱間衝撃圧縮 後に検出されていないことから, $800^{\circ} \mathrm{C}$ 付近で衝撃圧力を負荷 することで, $\mathrm{Sm}$ と $\mathrm{Fe}$ の拡散が抑制されているためと考えら れる. 実際, 熱間衝撃圧縮法の装置を用いて SHS 反応終了 後, そのまま $6 \mathrm{~min}$ 放置し, 室温まで冷却した後, 固化した ところ, X 線回折より冷間衝撃圧縮材と同様な結果が得られ た.これは，上の結果を支持するものと思われる.

\section{3 微細組織観察及び組成分析}

SHS 反応後, 得られた試料断面のSEMによる組成像を 図 8 に示す. 図 $8(\mathrm{a}) \sim(\mathrm{d})$ は順に, $R=2: 7,2: 11,2: 14$ そし て2:17の試料に対応している.これらの試料には, 灰色, 白 色，及び黒色の三つの領域が観察され，白色と黒色の領域は灰 色の領域をマトリックスとして分散している，また，出発組成 の $\mathrm{Fe}$ の割合が減少し $R=2: 7$ 組成に近づくにつれて, 灰色の 領域が増加していことが分かる. EDS 分析の結果, この領域 の組成は, $\mathrm{Sm}-\mathrm{Fe}-\mathrm{N}$ 系磁性体の前駆体である $\mathrm{Sm}_{2} \mathrm{Fe}_{17}$ 相であ ることが分かった．合成された試料内に打ける，この $\mathrm{Sm}_{2} \mathrm{Fe}_{17}$ 相の生成割合は, SEM 写真から判断して, $R=2: 7$ の組成で （図 8 (d)），およそ80\%以上と見積もられる。それとは逆に, 出発組成の $\mathrm{Fe}$ の割合が増加すると, 黒色の領域が増加してい ることが分かる．この約 $1 \sim 10 \mu \mathrm{m}$ 程度の大きさの黒色組織 は, EDS 分析の結果, $\alpha$ - Fe 相であることが分かった. また, 同時に観察された 1 $5 \mu \mathrm{m}$ 程度の白色領域は酸素を多く含ん た Sm-rich 相であることも分かった．これらの結果は，前述 のX 線回折結果 (3.2節) とも一致している.

次に図 9 に $R=2: 7$ 組成を持つ試料の (a)SHS 反応後, (b) 

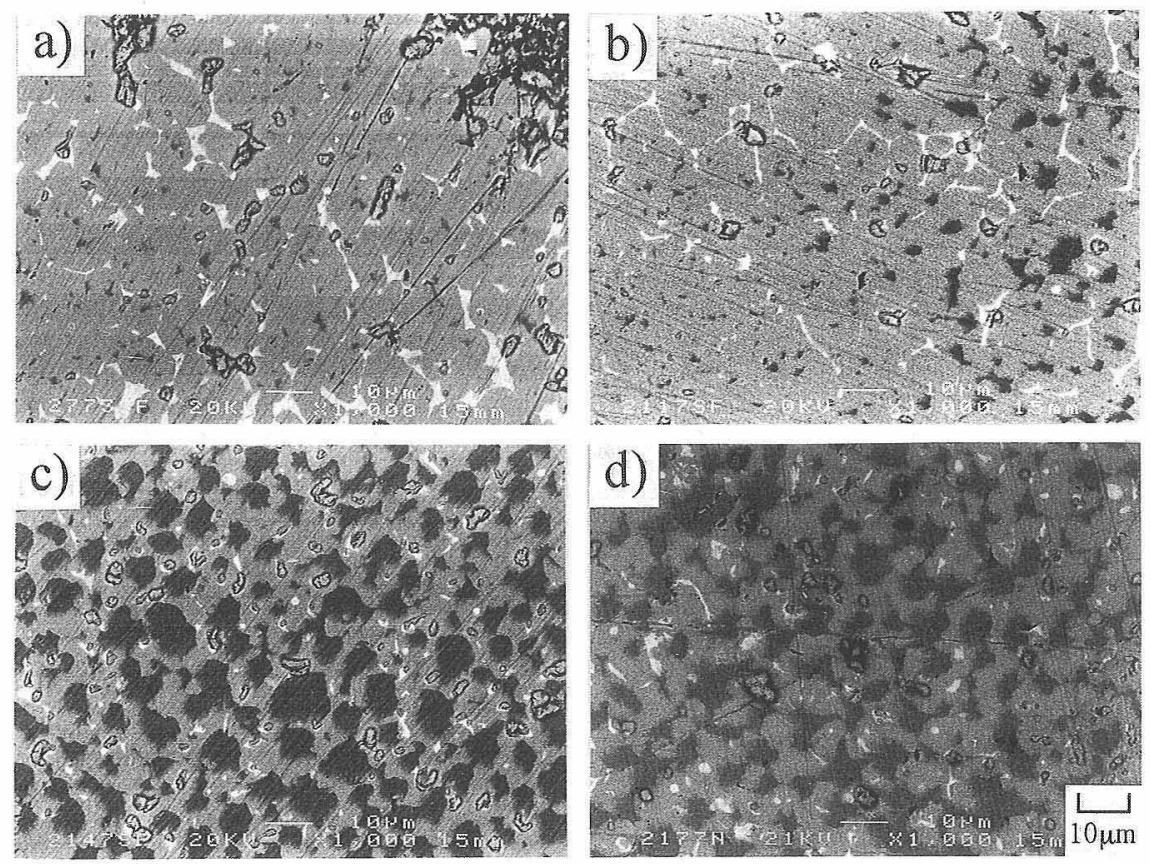

Fig. 8. Composition images of samples with compositions of (a) $\mathrm{Sm}: \mathrm{Fe}=2: 7$ (molar ratio), (b) $2: 11$, (c) $2: 14$ and (d) $2: 17$ produced by SHS reaction.
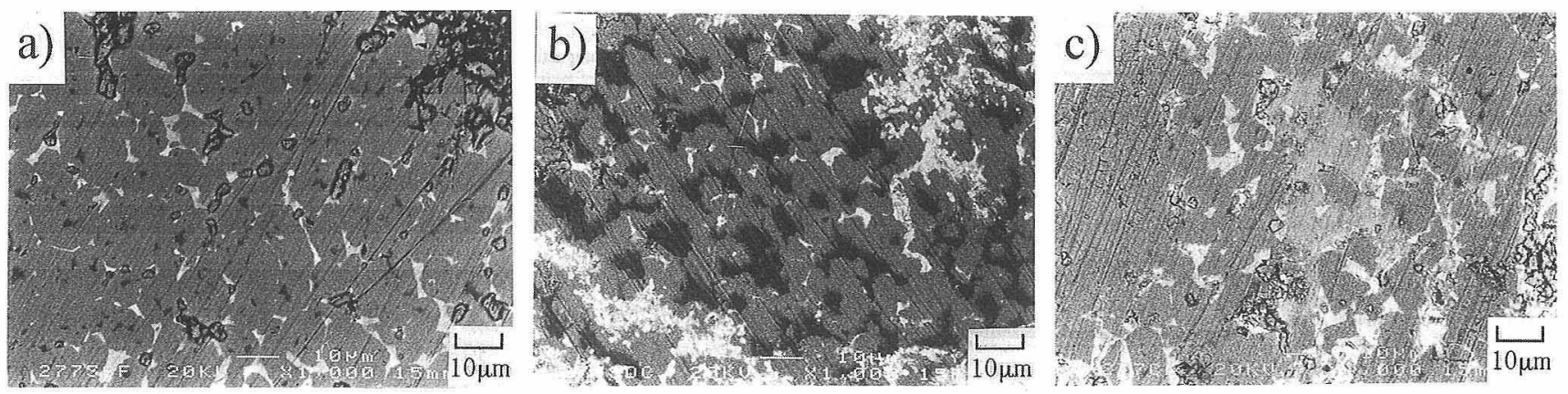

Fig. 9. Composition images of samples with a composition of $\mathrm{Sm}: \mathrm{Fe}=2: 7$ (molar ratio) (a) after the SHS reaction, (b) hot-, and (c) cold-shock compactions.

熱間及び (c) 冷間衝撃王縮後のSEM による組成像を示す。衝 撃圧縮後の試料には, SHS 反応後の試料と同様の灰色, 白色, 及び黒色の三つの領域が確認され，いずれも図 8 の結果と同 じ相が観察された. SHS 反応後と冷間衝撃圧縮後の両試料で は，X 線回折の結果（図 7）を支持して，同様の組織が観察さ れた。 また, 冷間衝撃圧縮材では, 先に述べた灰色の組織とは 異なった若干薄い灰色を示す領域が存在したＥDS 分析の結 果，その領域は $\mathrm{SmFe}_{2}$ 相であることが分かった，一方，熱間 衝撃圧縮材では，前述のように Sm と Fe の拡散が抑制された ことに伴う，黒色で表された $\alpha$ - Fe 相の領域が多く見られ，他 の二つの材料とは異なる組織形態を示した。

\section{4 磁気特性}

SHS 反応により得られた各試料の飽和磁化の值を図 10 K示 す.ここで，図中の飽和磁化の単位に質量磁化を用いたのは前 述のとおり，試料が複数の相で構成され，それらの構成割合に ついても不明であるために試料全体の密度を求められない，す なわち正確な体積が求められなかったためである. $\mathrm{Sm}_{2} \mathrm{Fe}_{17}$ 相 が少ない $R=2: 17$ 試料においては, 高い值を示しており, 逆に同相が主相の $R=2: 7$ 組成では，現在までに報告されて いる窒化処理前の $\mathrm{Sm}_{2} \mathrm{Fe}_{17}$ 化合物の值 ${ }^{10)}$ と比較すると若干低

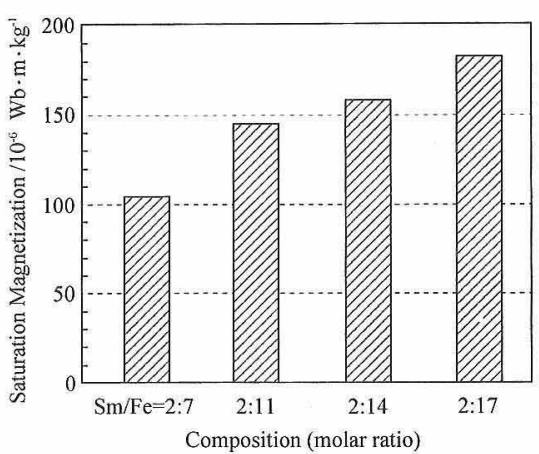

Fig. 10. Saturation magnetization of samples with various compositions.

いものの $103 \times 10^{-6} \mathrm{~Wb} \cdot \mathrm{m} / \mathrm{kg}$ の值が得られた. $R=2: 17 の$ 試 料では未反応 $\alpha-\mathrm{Fe}$ 相の存在が影響していると思わ㧈る. 女 た, 最も $\mathrm{Sm}_{2} \mathrm{Fe}_{17}$ 化合物の生成量が多かった $R=2: 7$ 組成で も，3.3節でも述べたとおり，その生成割合が $80 \%$ 程度であっ たことから，他の生成物である $\mathrm{SmFe}_{2}$ 相, 及び酸素を若干固 溶した Sm-rich 相などの影響を受け，磁気特性は向上しな 


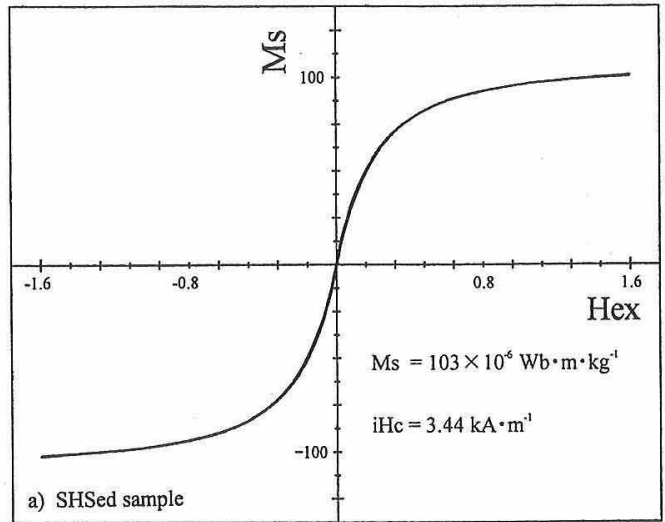

Ms : Saturation Magnetization [Unit : $10^{-6} \mathrm{~Wb} \cdot \mathrm{m} \cdot \mathrm{kg}^{-1}$ ]

Hex : Magnetic Field

[Unit : $\mathrm{MA} \cdot \mathrm{m}^{-1}$ ]

iHc : Coercive Force
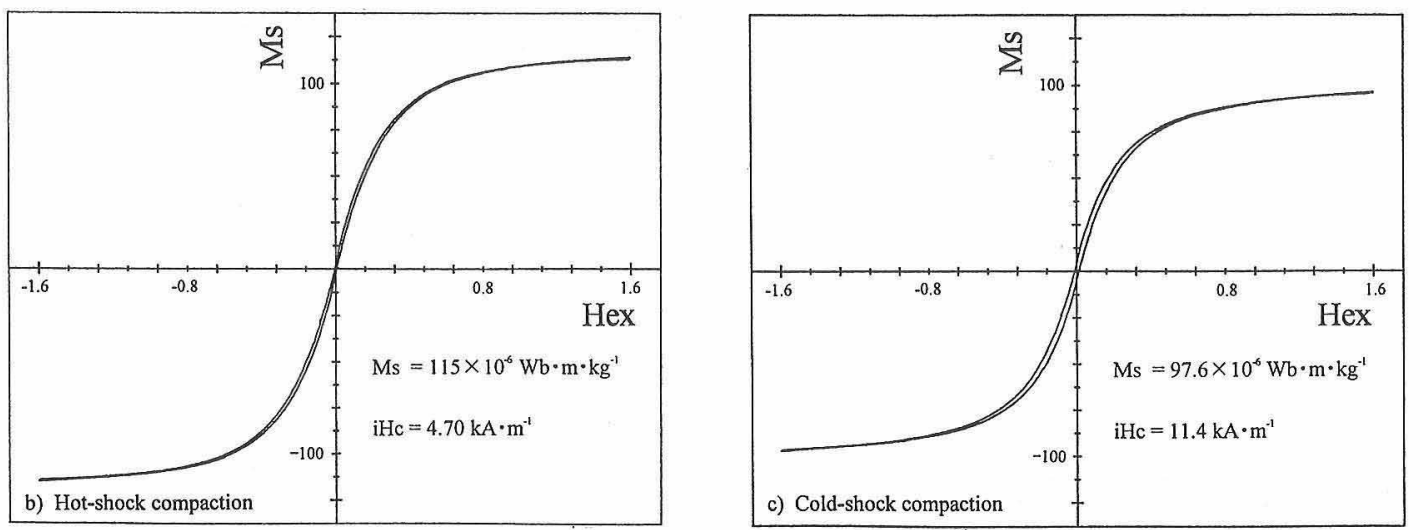

Fig. 11. Magnetic hysteresis loops of samples with a composition of $\mathrm{Sm}: \mathrm{Fe}=2: 7$ (molar ratio) (a) after the SHS reaction, (b) hot-, and (c) cold-shock compactions.

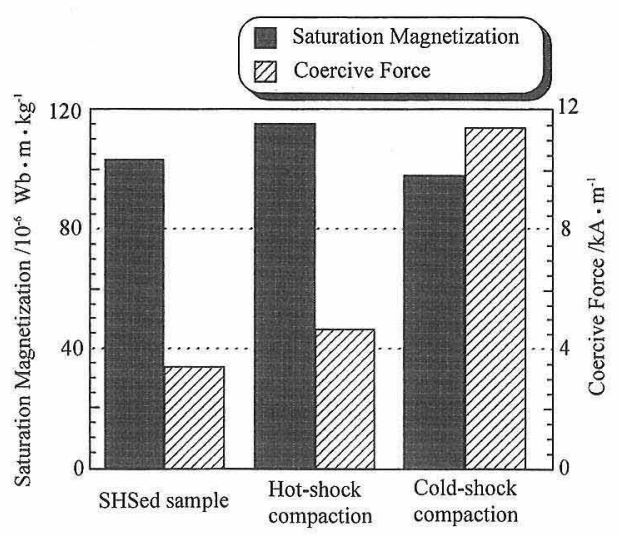

Fig. 12. Saturation magnetization and coercive force of samples with a composition of $\mathrm{Sm}: \mathrm{Fe}=2: 7$ (molar ratio) after various treatment.

かったむのと考兄られる.

次に，図11はSHS 反応後の試料と，熱間及び冷間衝撃圧縮 実験後に得られた試料の $M-H$ 曲線を，そして図12には各处理 後の飽和磁化と保磁力の関係を示した．飽和磁化の最高値は, 熱間衝撃圧縮後の試料で $115 \times 10^{-6} \mathrm{~Wb} \cdot \mathrm{m} / \mathrm{kg}$ であり, 他の試 料については, この值を若干下回っていた. しがしながら, 保 磁力の值に関しては, 冷間衝撃圧縮後の試料が他の二つの試料 に比べて高い值の $11.4 \mathrm{kA} / \mathrm{m}$ を示した. ここで著者らの数名 が, 以前, 金属間化合物粉末の泠間衝撃圧縮を行った際に得ら れた成形体の観察を行ったところ, 粉末粒間に白色の薄い層が
形成され，その薄い層は衝撃波の通過による粉末粒子同士の摩 擦で形成されたものであることを報告した．そして，透過型電 子䫓微鏡観察の結果, 粉末粒内部には衝撃波の通過に伴った強 加工による大量の転位が残留していたものの，その溶融層内に は，格子欠宿は見られなかった17)。これは爆発衝撃圧縮の特 徵であり, 粉末粒表面の局所的な摩擦熱は粉末内部まで拡散せ ずに，格子欠陥むまた除去されないことを示している．本研究 における $\mathrm{Sm}-\mathrm{Fe}$ 系合金においても，衝撃圧縮の間に同様のこ とが生じていることが容易に予想される。すなわち，衝撃圧縮 により生じた格子欠楩が，磁壁の移動を好げ，比較的高い保磁 力を発現させたものと思われる。しかしながら， Sm-Fe-N系 永久磁性材料は, ニュークリエイション型の保磁力発生機構を 持つ材料であることが知られており，衝撃压縮による格子欠陌 の導入は $\mathrm{Sm}-\mathrm{Fe}-\mathrm{N}$ 系磁性体にとっては逆磁区発生サイトに なりやすいため, 不向きかもしれない，むしろ，欠宿の存在に より磁壁の移動を妨げて保磁力を向上させる，ピンニング型の 保磁力発生機構を持つ試料に対しては，有効な要因となり得る と思われる.

\section{4. 結 論}

サマリウム及び鉄粉末を用いた SHS 反応により， Sm- $\mathrm{Fe}$ 系合金を短時間で作製することができたまた，その試料に熱 間及び泠間で爆発衝撃超高圧力を負荷することで緻密な成形体 を得た．本実験により得られた結果を以下に示す。

（1）各種混合粉末について燃焼温度を測定したところ，

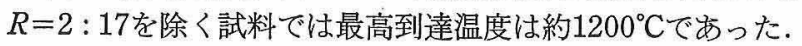

(2) $\mathrm{X}$ 線回折, 組成像及び $\mathrm{EDS}$ 分析結果から, $\mathrm{Sm}_{2} \mathrm{Fe}_{17}$ 
相, $\mathrm{SmFe}_{2}$ 相, 酸素を含んた Sm-rich 相, $\mathrm{SmN}$ 及び $\alpha$ - Fe 相 の五つの相が確認され，試料の単相化を更に促進させる必要が めった.

（3）冷間衝撃圧縮後の試料に扔いて保磁力の向上が見られ た。これは衝撃圧縮によって格子欠陥（転位）が $\mathrm{Sm}_{2} \mathrm{Fe}_{17}$ 相 内に導入され，格子歪みを生じたことに起因すると思われる.

謝辞 本研究の一部は平成 9 年度文部省科学研究費補助金 (奨励研究 $(\mathrm{A})$ : 課題番号 09750799) の御援助を受けたことを記 し，謝意を表します。また，本研究を遂行するに当たり，爆発衝 撃固化実験で熊本大学工学部附属衝撃エネルギー実験所・石谷幸 保助手に御協力頂きむした.VSM の使用に際して熊本工業大学工 ネルギーエレクトロニクス研究所・八木正昭教授ならびに宗像 誠助教授に御協力頂きました。ここに記して深く感謝致します。

(1998年10月第11回日本セラミックス協会秋季シンポジウムに て一部発表)

\section{文 献}

1) Nensho Gosei Kenkyukai Hen, "Nensho Gosei no Kagaku, "T.I.C. (1992) pp. 1-60 [in Japanese].

然焼合成研究会編, “燃焼合成の化学, ”ティー・アイ・ シィー社 (1992) pp. 1-60.

2) R. Tomoshige, Y. Kakoki, A. Chiba, K. Imamura and T. Matsushita, J. Ceram. Soc. Japan, 103, 634-38 (1995) [in Japanese].

3) R. Tomoshige, S. Okuma, M. Katagiri, T. Matsushita, K. Imamura and A. Chiba, J. Japan Explos. Soc., 57, 231-37 (1996) [in Japanese].

4) R. Tomoshige, A. Murayama and T. Matsushita, J. Am. Ceram. Soc., 80, 761-64 (1997).

5) H. Tanaka, R. Tomoshige, A. Kato, K. Imamura and A. Chiba, J. Japan Explos. Soc., 59, 153-59 (1998) [in Japanese].

6) J. M. D. Coey and H. Sun, J. Magn. Magn. Mat., 87, L251-54 (1990).

7) K. Kobayashi, Y. Iriyama, N. Imaoka and T. Fukuda, Rare Earth, 19, 31-43 (1991) [in Japanese].

8) Seramikkusu Henshuiinkai, Kiso Kogaku Koza Sho Iinkai
Hen, "Seramikkusu no Fukugoka-Kagaku to Gijutsu ," Nippon Seramikkusu Kyokai (1997) pp. 148-63 [in Japanese].

セラミックス編集委員会基礎工学講座小委員会編, “セラ ミックスの複合化一一科学と技術——, ”学—本セラミックス 協会 (1997) pp. 148-63.

9) M. Itoh, K. Majima, S. Katsuyama and H. Nagai, J. Japan Inst. Metals, 59, 666-72 (1995) [in Japanese].

10) S. Sugimoto, M. Okada and M. Honma, Dai 78 kai Nippon Ouyo Jiki Gakkai Kenkyukai Shiryo (1993) pp. 69-74 [in Japanese].

杉本 諭, 岡田益男, 本間基文, 第78回日本応用磁気学会研 究会資料 (1993) pp. 69-74.

11) R. Tomoshige, Y. Kakoki, A. Chiba, K. Imamura and T. Matsushita, "Metallurgical and Materials Applications of ShockWave and High-Strain-Rate Phenomena," Ed. by L. E. Murr, K. P. Staudhammer and M. A. Meyers, Elsevier Science B. V., Amsterdam, Lausanne, New York, Oxford, Shannon, Tokyo (1995) pp. 67-74.

12) R. Tomoshige, A. Chiba, M. Nishida and T. Matsushita, "Advanced Materials '93, I/A: Ceramics, Powders, Corrosion and Advanced Processing," Vol. 14A, Ed. by N. Mizutani, M. Yoshimura, H. Kawamura, K. Kijima and M. Mitomo, Trans. Mater Res. Soc. Jpn., Elsevier Science B. V., Amsterdam, Lausanne, New York, Oxford, Shannon, Tokyo (1995) pp. 643-46.

13) T. B. Massalski, "Binary Alloy Phase Diagrams," Second ed., Vol. 2, Ed.by H. Okamoto, P. R. Subramanian and L. Kacprzak, ASM International, Materials Park, OH (1990) pp. 1771-73.

14) Y. Iriyama, K. Kobayashi, H. Kato and Y. Nakagawa, $J$. Magn. Soc. Jpn., 16, 153-58 (1992) [in Japanese].

15) I. Barin, "Thermochemical Data of Pure Substances," Third ed., Vol. I, VCH, Weinheim, New York, Basel, Cambridge, Tokyo (1995) pp. 507-843.

16) I. Barin, "Thermochemical Data of Pure Substances," Third ed., Vol. I, VCH, Weinheim, New York, Basel, Cambridge, Tokyo (1995) pp. 929-1826.

17) R. Tomoshige, A. Chiba, M. Nishida, K. Imamura, M. Kodama and T. Matsushita, J. Japan Explos. Soc., 55, 166-73 (1994) [in Japanese]. 